\title{
Gene Knock-Out Model
}

National Cancer Institute

\section{Source}

National Cancer Institute. Gene Knock-Out Model. NCI Thesaurus. Code C18803.

Models of human disease produced through gene knockout methods 